\title{
TM(TM=Fe, Co, Ni)/N/O tri-doped Graphene Heterogeneous Electrocatalysts for Oxygen Reduction Reaction: A Theoretical Insight
}

\author{
L. B. Yu, J. Wu, Q. Y. Huang, S. S. Liu, L. Yang*
}

School of Energy and Power Engineering, Jiangsu University of Science and Technology, Zhenjiang, 212003, China

*E-mail: yljust18@163.com

Received: 15 May 2021 / Accepted: 6 July 2021 / Published: 10 August 2021

Density functional theory (DFT) is utilized to compute the thermodynamic free energy changes of the elementary reaction steps of the oxygen reduction reaction $(\mathrm{ORR})$ on $\mathrm{TMO}_{\mathrm{x}} \mathrm{N}_{4-\mathrm{x}}(\mathrm{TM}=\mathrm{Fe}, \mathrm{Co}$ and $\mathrm{Ni}$; $\mathrm{x}=1-3)$ single atom catalysts $\left(\mathrm{TMO}_{\mathrm{x}} \mathrm{N}_{4-\mathrm{x}-\mathrm{SACs}}\right)$. Based on thermodynamic stability and catalytic ORR activity, it is found that $\mathrm{CoO}_{\mathrm{x}} \mathrm{N}_{4-\mathrm{x}} \mathrm{SACs}$ show relatively good stability and activity. Furthermore, the final reduction reaction step $\left(\mathrm{OH}^{*}+\mathrm{H}^{+}+\mathrm{e}^{-} \rightarrow \mathrm{H}_{2} \mathrm{O}+*\right)$ with the largest $\Delta \mathrm{G}$ value towards five different $\mathrm{CoO}_{\mathrm{x}} \mathrm{N}_{4-\mathrm{x}}-\mathrm{SACs}$ is the potential-determining step (PDS). All calculated results suggest that the theoretical overpotential of $\mathrm{CoO}_{2} \mathrm{~N}_{2}$-opp is munch close to that of Pt (111), implying the optimal electrocatalytic ORR activity among $\mathrm{TMO}_{\mathrm{x}} \mathrm{N}_{4-\mathrm{x}} \mathrm{SACs}$. Furthermore, electronic structure analysis reveals that the $d$-band center of $\mathrm{Co}$ for $\mathrm{CoO}_{2} \mathrm{~N}_{2}$-opp is located rather far away from the Fermi level (set as zero) and binding states of adsorbed are reduced and the antibinding states of adsorbed $\mathrm{OH}^{*}$ fragments are increased, compared with that of other $\mathrm{CoO}_{\mathrm{x}} \mathrm{N}_{4-\mathrm{x}}-\mathrm{SACs}$. In conclusion, the introduction of $\mathrm{N}$ and $\mathrm{O}$ can effectively modify $d$-band of active metal center and adsorption of oxygen-contained intermediates, thus tune ORR activity.

Keywords: density functional theory, oxygen reduction reaction, single atom catalysts

\section{$\underline{\text { FULL TEXT }}$}

(C) 2021 The Authors. Published by ESG (www.electrochemsci.org). This article is an open access article distributed under the terms and conditions of the Creative Commons Attribution license (http://creativecommons.org/licenses/by/4.0/). 